\title{
GEOMETRIC MODEL OF MICROSCOPIC RAPHIDE CRYSTALS IN PLANT CELLS
}

\section{Ali ÖZDEMIR}

Manisa Celal Bayar University, Faculty of Science and Art, Department of Mathematics, Şehit Prof. Dr İlhan Varank Campus 45140 Manisa, Turkey

E-mail: acaozdemir@gmail.com

\begin{abstract}
Özdemir A., 2021: Geometric model of microscopic raphide crystals in plant cells. - Botanica, 27(1): 62-68.

In the present study, we showed that the microscopic structures of some plant crystals have the geometric model and mathematical formulas. Plant crystals are the storage of many mineral acid salts in many plants, such as chloride, phosphate, carbonate, silicate anhydrides and sulfates, formed due to metabolism. The crystals formed take different shapes. The shaping of plant crystals is not a simple structure. They are created in specific shapes and sizes by this biomineralisation process. Seventy-five per cent of flowering plants make one or more kinds of crystals. One of these is called a raphide crystal. Our study determined that the microscopic structures of some raphide crystals show the elongated triangular bipyramid that is a mathematics definition. In geometry, the elongated triangular bipyramid is one of the Johnson solids $\left(\mathrm{J}_{14}\right)$, convex polyhedra, whose faces are regular polygons. At the same time, it was determined that the crystals show a minimal surface feature. The feature takes an essential place in geometry. The minimal surface feature provides the advantages of resistance and minimal space occupation to the crystals.
\end{abstract}

Keywords: elongated triangular bipyramid, geometric model, minimal surface, raphide crystal.

\section{INTRODUCTION}

Plant crystals are the storage of many mineral acid salts formed due to metabolism in many plants. Some of these inorganic salts are harmful to the plant. These combine with the plant's calcium and turn into crystals and become harmless to plant cells. Plant crystals exhibit an astonishing variety of morphology as defined in different categories by botanists. The shaping of plant crystals is not a simple structure; they are formed in specific shapes and sizes by this biomineralisation process (VINCENT \& Paul, 2005; Bouropoulos et al., 2001). Some of these are geometric structures made up of regular prismatic shapes (FrANCESCHI \& Horner, 1980). One of these is raphide crystals, which were investigated in the present study. They are identifiable formations with unique geometric shapes expressed in formulas in mathematics. It was observed in the research that some raphide crystals have elongated triangu- lar bipyramid prismatic structures. In geometry, the elongated triangular bipyramid is one of the Johnson solids (JoHnson, 1966). The prismatic structures that we observed also have a minimal surface, which is a mathematical concept and a surface that minimises its occupied space. This is equivalent to having zero mean curvature. The term "minimal surface" is used because these surfaces originally arose as surfaces that minimised total surface area subject to some constraint. These features give them advantages such as taking up less space and solidity (GrAY, 1997).

We examined the raphide crystals that can only be seen using a microscope in some plant samples for their geometric structure. Different crystals have been observed in some parts of plants (ÖZDEMIR et al., 2016; Aкyol et al., 2018a, b). Some studies on the geometric definitions of the parts of some living things that can be seen with the naked eye are available in the literature (OPPENHEIMER, 1986; KAITANIEMI et al., 2000; Fernandez et al., 2004; Pradal et al., 
2009). But studies on the geometric features of the microscopic structures of living things are limited (Özdemir, 2018, 2020; Korn \& Spalding, 1973). We hypothesised that the microscopic structure of plant crystals has a geometric structure that can be expressed mathematically. This study observes geometric concepts such as minimal surfaces and elongated triangular bipyramid structures in plant crystals. The micro-morphological structure of plant crystals and their geometric definitions expressed by mathematical formulas were provided.

\section{MATERIALS AND METHODS}

\section{Plant material}

The plants belonging to geophytes, which commonly have raphide crystals in their roots, were used in the study.

The roots of three species, Muscari parviflorum Desf., Ophrys vernixia ssp. regis-ferdinandii (Acht. \& Kellerer ex Kuzmanov) Renz \& Taub. and Ophrys lutea ssp. minor (Guss.) O. \& E. Danesch), were collected in their flowering period between March and August from their natural habitats in the western Anatolian Region of Turkey in 2019.

\section{Anatomical assessment}

For micromorphological evaluation, small pieces of 2-3 cm were taken from the roots of the plants collected since the crystals are seen more in these parts of the plants. The pieces were fixed in $70 \%$ ethyl alcohol $\left(\mathrm{C}_{2} \mathrm{H}_{5} \mathrm{OH}\right)$. The sections were taken from the fresh samples and alcohol preserved samples of the plant roots. The anatomical sections were stained with safranin and fast green (BozDAG et al., 2016). Micromorphological structures of the plant samples were investigated using a light microscope Leica DM 3000. Then the crystal photos were taken using a motorised Leica DM 3000 microscope. Photomicrographs were generated and analysed using a Mira 3 Tescan FESEM (Vincent \& Paul, 2005; Santos et al., 2018).

\section{Mathematical methods}

In the mathematical evaluations, the definitions of minimal surface, the Johnson solids and elongated triangular bipyramid, which are mathematical concepts, were used to describe the crystals' geometric structures. Literature information on geometric structures and their mathematical formulas were evaluated (Johnson, 1966; Hoffman \& William, 1987; GrAY, 1997).

\section{RESULTS AND DISCUSSION}

Our study observed that the microscopic structures of the plant crystals show the different prismatic features of geometric structure. It was determined that the prismatic structures of some raphide crystals are geometrically defined as elongated triangular bipyramid. At the same time, the prismatic crystals display a minimal surface feature, which takes an essential place in geometry. The mathematical minimal surface can also be characterised as the surface of minimal surface area for given boundary conditions. Has found that a plane is a trivial minimal surface, and the first examples of catenoid and helicoid were given in 1776. Hoffman (1987) has demonstrated the existence of an infinite number of such surfaces by discovering a three-pronged type on one minimally hidden surface. Thus, he has shown that a surface could be parameterised using an isothermal parameterisation. Before Hoffman, the catenoid, helicoid and plane were considered minimal surfaces, boundless and no self-intersections of known finite topology (HofFman, 1987). A surface can be parameterised using an isothermal parameterisation, if the coordinate functions $x_{k}$ are harmonic, i.e. $\varnothing_{k}(\zeta)$ are analytic, such a parameterisation is minimal (HofFMAN \& WILLIAM 1987). Therefore, a minimal surface can be represented by a triple of analytic function as

$$
\varnothing_{1}^{2}+\varnothing_{2}^{2}+\varnothing_{3}^{2}=0
$$

The real parameterisation is then obtained as $x_{k}=R \int \varnothing_{k}(\zeta) d \zeta$.

On the other hand, for an analytic function $f$ and $a$ meromorphic function $g$, the triple of functions

$$
\begin{aligned}
& \emptyset_{1}(\zeta)=f\left(1-g^{2}\right) \\
& \emptyset_{2}(\zeta)=i f\left(1+g^{2}\right) \\
& \emptyset_{3}(\zeta)=2 f g
\end{aligned}
$$

are analytic as long as $f$ has a zero order $\geq m$ at every pole of $g$ of order $m$. This result gives us a minimal surface in terms of the Enneper-Weierstrass parameterisation 


$$
R \int\left|\begin{array}{c}
f\left(1-g^{2}\right) \\
i f\left(1+g^{2}\right) \\
2 f g
\end{array}\right| d \zeta
$$

The crystals of the test plant samples with the minimal surface area have an elongated triangular geometric pattern of bipyramid.

\section{Elongated triangular bipyramid}

The elongated triangular bipyramid is one of the Johnson solids $\left(\mathrm{J}_{14}\right)$. In geometry, the Johnson solid is a strictly convex polyhedron, each face of which is a regular polygon. There is no requirement that each face must be the same polygon or that the identical polygons join around each vertex. The Johnson solid is one of 92 convex polyhedra. They were named by Norman Johnson, who first listed these polyhedra in 1966 (Johnson, 1966). The present study determined that the microscopic structures of raphide crystals have the 14th Johnson solid $\left(\mathrm{J}_{14}\right)$. It has eight vertices, 15 edges, nine faces (six equilateral triangles and three squares). Its $\left(\mathrm{J}_{14}\right)$ symmetry group is dihedral. In mathematics, a dihedral group is the group of symmetries of a regular polygon, including rotations and reflections.

The following formulas for volume (V), surface area (A) and height $(\mathrm{H})$ can be used if all faces are regular, with edge length a:

$$
V=\left(\frac{1}{12}(2 \sqrt{2}+3 \sqrt{3})\right) \cdot a^{3} \approx 0.668715 \ldots a^{3}
$$$$
A=\left(\frac{3}{2}(2+\sqrt{3})\right) \cdot a^{2} \approx 5.59808 \ldots a^{2}
$$

$$
H=\frac{3+2 \sqrt{6}}{3} \cdot a \approx 2.63299 \ldots a
$$

The Cartesian coordinates of the elongated triangular bipyramid with edge length 2 are:

$$
\begin{aligned}
& (0,0, \pm(1+\sqrt{ }(8 / 3))) \\
& ( \pm 1,-1 / \sqrt{ } 3, \pm 1) \\
& (0,2 / \sqrt{ } 3, \pm 1)
\end{aligned}
$$

These definitions and microscopic images of the investigated plant samples were shown in Figs 1-4.

We examined the geometric structure of raphide crystals that can only be seen using a light or an electron microscope in the presented samples. The raphide crystals have a prismatic structure and can be defined as geometric models in mathematical formulas. It was shown that the raphide crystal structure in the micromorphological structure of plants could be described by an elongated triangular bipyramid, which is the Johnson solid $\left(\mathrm{J}_{14}\right)$ geometric structure. In addition, it was observed that these geometric structures have a minimal surface. A minimal surface is a surface with zero mean curvature in all points (GRAY, 1997). These geometric shapes provide them with some significant advantages such as taking up less space and durability. The researchers have pointed that crystals within organs of plants are possibly involved in Ca regulation, protection against herbivores, and provide tissue strength to the plant structures (COTE \& GiBernaU, 2012). The present study concretely confirms the determinations of the researchers with geometric results.

Studies on some visible geometric structure examples and related to the visible external structures of plants have been presented (Melo \& ANDRADE, 2018; Oppenheimer, 1986; KaitAniemi et al., 2000). However, there are only a few geometric studies on plant micromorphological structures. The researchers have studied the geometric structures of plants' epidermis cells and glandular hairs (KoRn \& SPALDING, 1973; ÖZDEMIR, 2018, 2020). There are some studies on microscopic images of plant crystals in the literature (Vincent \& Paul, 2005; Santos et al., 2018). However, none of the studies investigated the geometric properties of the microscopic structure
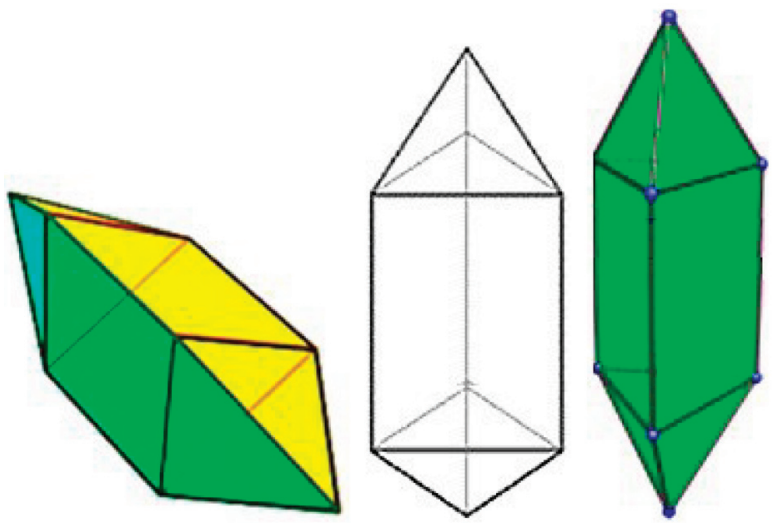

Fig. 1. Geometric representations of elongated triangular bipyramid $\mathbf{J}_{14}$ (Johnson, 1966) 
crystals. The species investigated for the study were specially selected as they belong to plants. Crystals are usually found in the roots of geophytes, which include the species selected for analysis (COTE \& GIB-
ERNAU, 2012; ThOMAs et al., 2006). The study results showed that geometric concepts such as minimal surfaces and elongated triangular bipyramid structures could be applied to describe plant crystals.

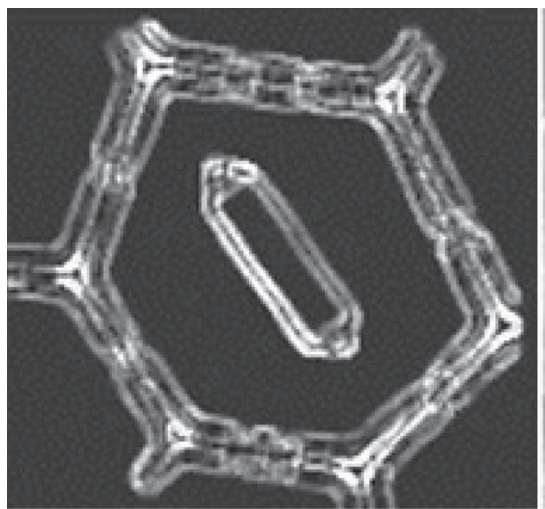

A

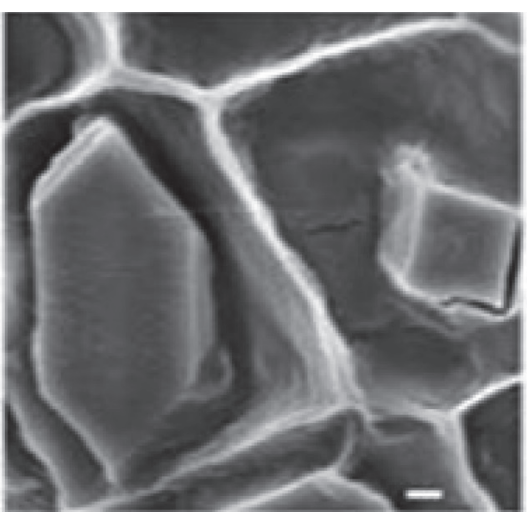

B

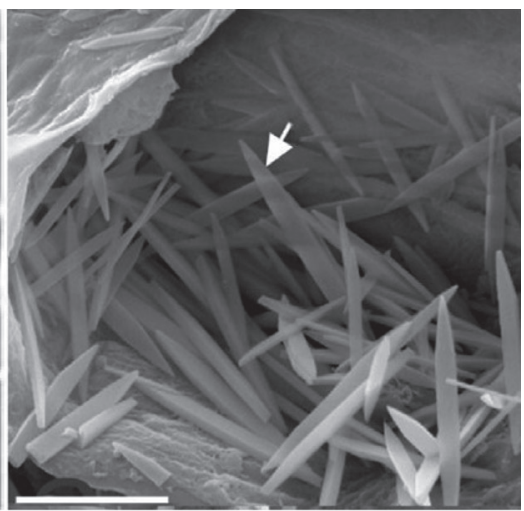

C

Fig. 2. The elongated triangular bipyramid crystals. A - illustration of micrographs of raphide crystals in a plant cell. B $-M e-$ dicago truncatula (crystal using SEM) (VINCENT \& PAUL, 2005). Scale bar: $1 \mu \mathrm{m}$. C - Piper caldense (raphide crystal using SEM) (SAntos et al., 2018). Scale bar: $5 \mu \mathrm{m}$
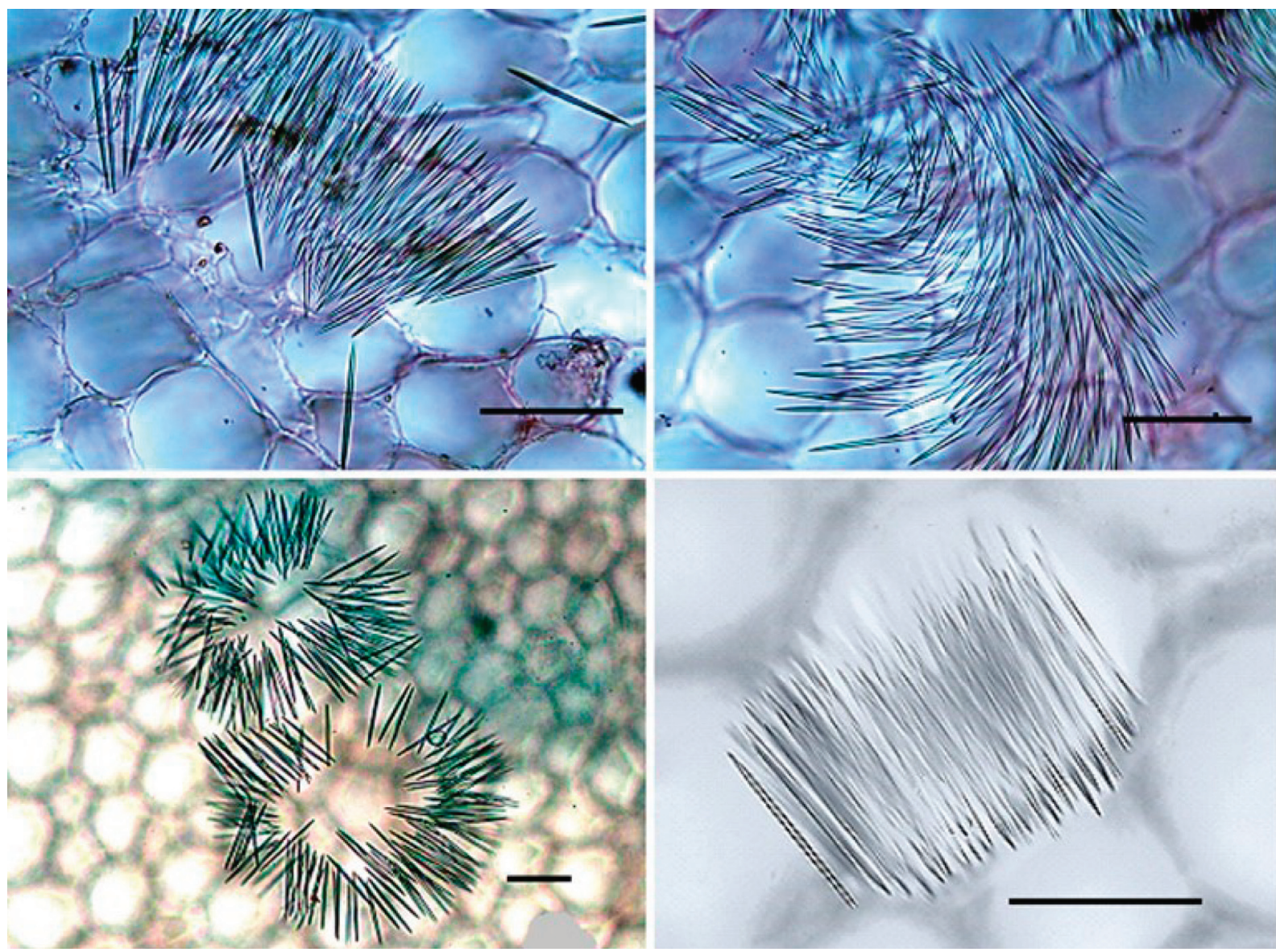

Fig. 3. The cross-sections of the root of Muscari parviflorum. Single and bundle raphide crystals observed using a light microscope. Scale bar $=10 \mu \mathrm{m}$ 

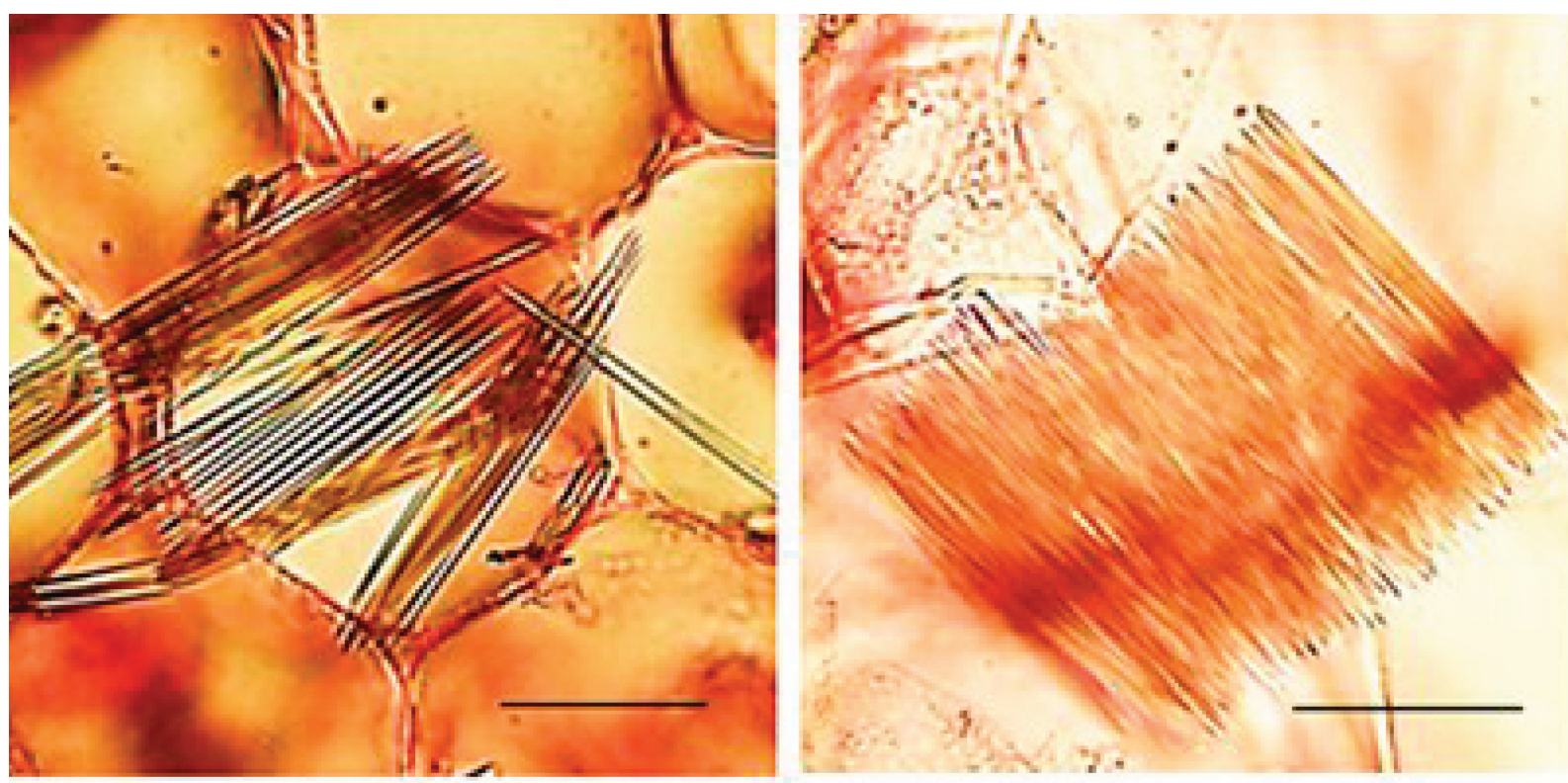

A
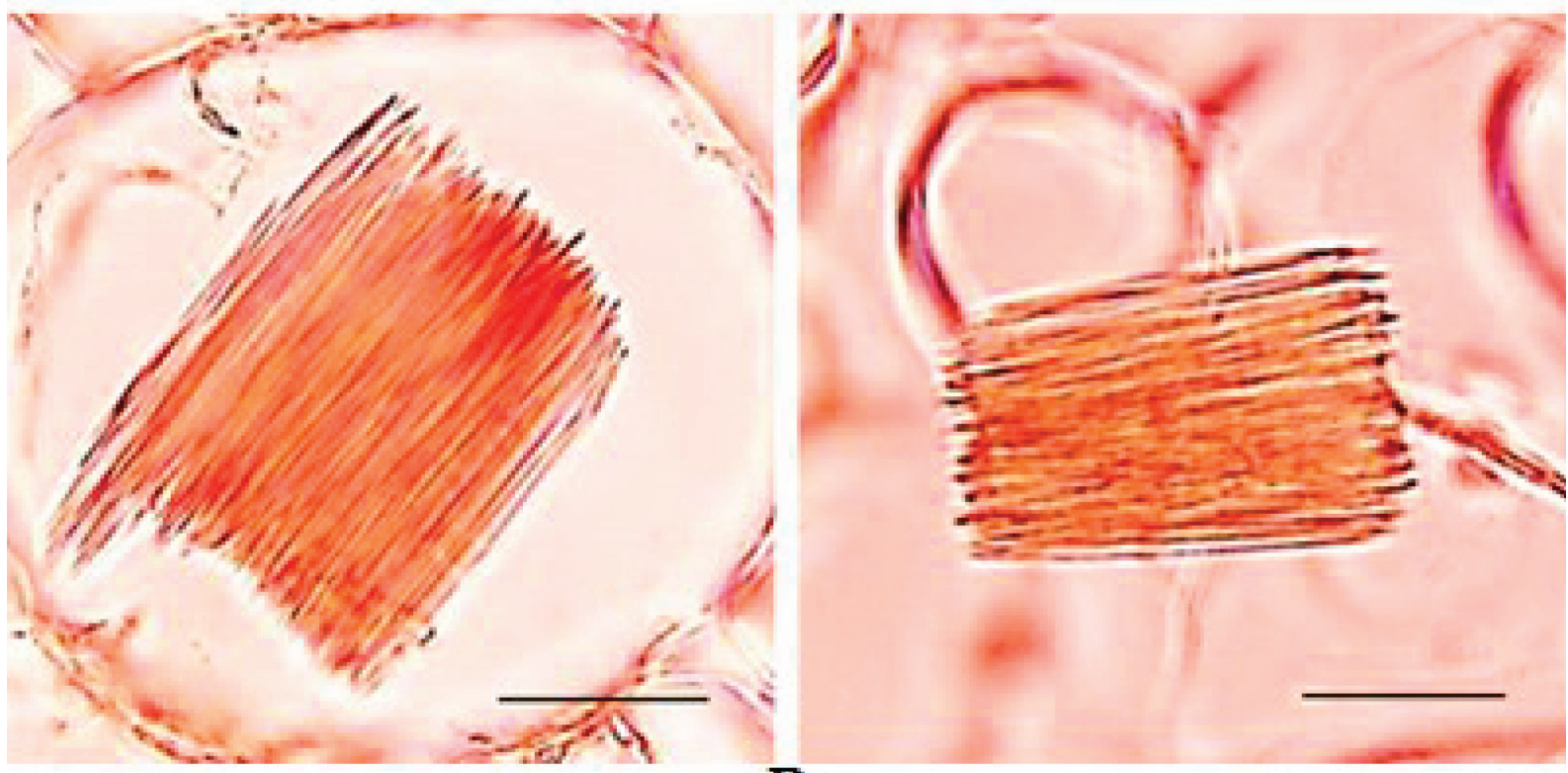

B

Fig. 4. The bundle raphide crystals in cross-sections of the root of Ophrys vernixia subsp. regis-ferdinandii (A) and O. lutea subsp. Minor (B) (using a light microscope). Scale bar $=10 \mu \mathrm{m}$

Along with the micromorphological structure of plant crystals, their geometric definitions expressed by mathematical formulas were provided. In this study, we tried to show that some micromorphological structures of plants have mathematical properties that can be expressed with formulas and geometric concepts. Mathematical properties such as the "prismatic and prismatic structures of bipyramid" observed in plant crystals are also possible in other plant micro-morphological structures. Thus, a different perspective was tried to be brought in plant anatomy studies. As a result, we believe that the study provides a new comparing opportunity for future researchers on the related subjects. 


\section{REFERENCES}

Akyol Y., Yetișen K., Kocabaș O., Özdemir C., 2018a: Arum nickelii Schott ve Monotipik Arisarum vulgare O.Targ.-Tozz. - KSU Journal of Agriculture and Nature, 21(2): 239-245.

Akyol Y., Durmuskahya C., Yetișen K., Kocabaș O., ÖzDEMIR C., 2018b: The anatomical studies on two Biarum (Araceae) species in Turkey. - Acta Botanica Hungarica, 60(1-2): 1-12.

Bouropoulos N., Weiner S., Addadi L., 2001: Calcium oxalate crystals in tomato and tobacco plants: Morphology and in vitro interactions of crystal associated macromolecules. - Chemistry European Journal, 7(9): 1881-1888.

BozdaĞ B., Kocabas O., Akyol Y., Özdemir C., 2016: New staining method for hand-cut in plant anatomy studies. - Marmara Pharmaceutical Journal, 20: 184-190.

Cote G.G., Gibernau M., 2012: Distribution of calcium oxalate crystals in floral organs of Araceae in relation to pollination strategy. - American Journal of Botany, 99: 1231-1242.

Fernandez J.W., Mithraratne P., Thrupp S.F., Tawhai M.H., Hunter P.J., 2004: Anatomically based geometric modelling of the musculo-skeletal system and other organ, Biomech. Model. Mechanobiology Journal, 2: 139-155.

FranCESCHI V.R., HorNer H.T., 1980: Calcium oxalate crystals in plants. - Botany Review, 46: 361-427.

Gray A., 1997: Minimal surfaces and minimal surfaces and complex variables. Ch. 30 and 31 in modern differential geometry of curves and surfaces with mathematica - 2nd ed. Boca Raton, FL, 681-734.

HOFFMAN D., 1987: The computer-aided discovery of new embedded minimal surfaces. -

Mathematical Intelligencer, 9: 8-21.

Hoffman D., William H., 1987: The global theory of properly embedded minimal surfaces. - Pacific Journal of Mathematics, 12: 361-366.
JohNSON N.W., 1966: Convex solids with regular faces. - Canadian Journal of Mathematics, 18: 169-200.

Kaitaniemi P., Hanan, J. S., Room P.M., 2000: Virtual sorghum; visualisation of partitioning and morphogenesis. - Computers and Electronics in Agriculture, 28: 195-205.

Korn W.R., Spalding R.M., 1973: The geometry of plant epidermal cells. - New Phytology, 72: 1357-1365.

Melo M., Andrade L., 2018: Minimal surfaces and soap bubbles in secondary school. - Revista Thema, 15(1): 51- 62 .

Pradal C., Boudon F., Nouguier C., Chopard J., Godin C., 2009: Plant GL, a python based geometric library for 3D plant modelling at different scales. - Graphical Models, 71: 1-21.

OpPenHeimer P., 1986: Real-time design and animation of fractal plants and trees. - Siggraph, 20: $55-64$.

ÖZDEMIR A., 2018: Geometric modelling and statistical comparison of some sage glandular hairs. - Fresenius Environmental Bulletin, 27: 6417-6421.

ÖzDEmIR A., 2020: Mathematical minimal surfaces in micromorphological structures of plants. - Fresenius Environmental Bulletin, 29: 7065-7070.

Özdemir A., Yetişen K., Akyol Y., Kocayiğit H., ÖzDEMIR C., 2016: A Statistical comparison of anatomical features in some ornithogalum sp. species 1. - Planta Daninha, 34: 485-495.

Santos V.L., Ramanb V., Bobek V.B., Migacz I.PÇ., Francod C.R.C., Khanb I.A., Budel J.M., 2018: Anatomy and microscopy of piper caldense, a folk medicinal plant from Brazil. - Revista Brasileira de Farmacognosia, 28: 9-15.

Thomas S., Barbara E.D., Stylianos D., 2006: Anatomical studies on the adventitious roots of the geophyte Urginea maritima (L.) Baker. - Journal of Biological Research, 5: 61-70.

Vincent R.F., Paul A.N., 2005: Calcium oxalate in plants: formation and function. - Annual Review of Plant Biology, 56: 41-71. 


\section{RAFIDŽIŲ MIKROSKOPINĖS STRUKTŪROS GEOMETRINIS MODELIS AUGALŲ LĄS- TELĖSE}

\section{Ali ÖZDEMIR}

\section{Santrauka}

Šiame tyrime mes parodème, kad kai kurių augalų kristalų mikroskopinès struktūros turi geometrini modelį, kurị galima aprašyti matematinėmis formulèmis. Augalų kristalai yra mineralinių rūgščių druskų, tokių kaip chloridas, fosfatas, karbonatas, silikato anhidridai ir sulfatai, kurie susidaro metabolizmo metu, sankaupos. Susiformavę kristalai yra skirtingu formų. Augalų kristalų forma nėra paprasta struktūra, jie pasižymi specifinèmis formomis ir dydžiais. Net
75\% žiedinių augalų kaupia vieną ar daugiau kristalų rūšių. Vieni iš jų vadinami rafidèmis. Buvo nustatyta, kad rafidès turi trikampę bipiramidinę formą, kurią galima matematiškai aprašyti. Geometrijoje pailga trikampe bipiramide yra viena iš Johnsono kietujų dalelių (J14), išgaubtų taisyklingų daugiakampių. Buvo nustatyta, kad kristalai turi minimalų paviršių, kuris suteikia jiems atsparumą ir minimalaus užimamo ploto pranašumą. 